\title{
Cryptography: Perancangan Middleware Web Service Encryptor menggunakan Triple Key MD5. Base64, dan AES
}

\author{
MAULYANDA ${ }^{1}$, SYAFRIAL FACHRI PANE², ROLLY MAULANA AWANGGA ${ }^{3}$
}

\author{
1,2,3Politeknik Pos Indonesia, Indonesia \\ Email : maulyanda@poltekpos.ac.id
}

Received 27 September 2021 | Revised 15 Oktober 2021 | Accepted 25 Oktober 2021

\begin{abstract}
ABSTRAK
Penelitian ini membantu dalam melalukan proses Keamanan data atau informasi untuk menjamin kerahasiaan dan keaslian data atau informasi. Dalam perancangan ini menggunakan Kriptografi sebagai salah satu solusi dalam mengamankan data atau informasi. Metode kriptografi digunakan untuk mempersatukan algoritma Md5, Base64 serta AES (Advanced Encryption Standard). Kombinasi dari tiga algoritma menghasilkan ciphertext, yang dapat mengamankan data dari proses tag NFC. Penelitian ini menggunakan metodologi penelitian yang dapat menyatakan bahwa sistem yang dibangun dapat berfungsi dengan baik dan untuk keamanan nya aman digunakan, dari hasil penerapannya didapatkan hasil persentase keberhasilan $100 \%$. Jadi, penelitian ini mampu menjawab permasalahan yang terjadi pada sistem keamanan data.
\end{abstract}

Kata kunci: Kriptografi, AES, Base64, Md5, RESTFul

\begin{abstract}
This research helps in carrying out data or information security to ensure the confidentiality and authenticity of data or information. This design uses Cryptography as a solution in securing data or information. Cryptographic methods to unify the Md5, Base64, and AES (Advanced Encryption Standard) algorithms. The combination of the three algorithms produces ciphertext, which can secure data from the NFC tag process. This study uses a research methodology that can state that the system built can function correctly, and for security, it is safe to use because it has a 100\% success percentage. So, this researchable to answer the problems that occur in the data security system.
\end{abstract}

Keywords: Cryptography, AES, Base64, Md5, RESTFul 


\section{PENDAhUluaN}

Kriptografi yaitu sebuah metode untuk menjaga keamanan data agar terjamin kerahasiaan data dan meningkatkan aspek keamanan saat penyampaian suatu data atau informasi (Panjaitan, Susanto, \& WM, 2017). Kriptografi mempunyai aspek keamanan yaitu melindungi, merahasiakan data atau informasi dari pemalsuan dan pengubahan informasi tersebut (Hidayat \& Afrianto, 2017). Kegunaan kriptografi kunci-publik yang penting adalah kunci, oleh karena itu pesan enkripsi menggunakan kunci privat Ketika proses pengiriman data atau informasi dan kunci tersebut ditempatkan pada data yang dikirimkan (Rohman \& Mufti, 2018). Para kriptografi, data atau informasi yang dapat dibaca disebut dengan plaintext, sedangkan data yang tidak terbaca atau tidak jelas disebut dengan cyphertext (Siswanto, Anif, \& Gata, 2018). Salah satu algoritma yang dipakai dalam kriptografi adalah AES (Advanced Encryption Standard) algoritma enkripsi kunci simetris pada saat ini (Masoumi \& Rezayati, 2014) (Sibarani, Zarlis, \& Sembiring, 2017). Sedangkan metode yang diterapkan pada algoritma kriptografi penyandi blok AES antara lain ECB, CBC, CFB serta OFB (Budianto, Amini, \& Ariyani, 2017). Teknologi untuk keamanan data memiliki tujuan untuk memenuhi kebutuhan proses bisnis dari pengguna atau organisasi suatu perusahaan. (Pane, Awangga, \& Maulyanda, 2018) (Pane, Awangga, \& Azhari, 2018). Web service digunakan untuk menghubungkan client dan server untuk dapat melakukan proses pertukaran data atau pesan (Christanto \& Kurniawati, 2016). RESTFul web service sangat baik dalam proses kinerja server yang stabil ketika digunakan secara bersamaan oleh pengguna (Carter, Khaire, Novosad, \& Chang, 2016). Namun keamanan RESTFul Web service merupakan poin penting yaitu mencangkup keamanan informasi, serta melindungi kerahasiaan informasi atau data tersebut (Awangga \& Andarsyah, 2016). Bahasa pemrograman python digunakan dalam penelitian ini karena beberapa alasan yaitu python bersifat open source (Permana, Praja, Fatkhuroyan, \& Muzayanah, 2018), dapat di optimalisasi (Tibau, Nunes, Bortoluzzi, \& Marenzi, 2018) (Moudgalya, 2018), dan Python adalah bahasa pemrogram multiguna dan sebuah program level tinggi yang dapat ditafsirkan (López, Pelayo, \& Forero, 2016). Jenis microframework yang digunakan untuk menjalankan kode python yaitu flask yang merupakan sebuah framework dari Bahasa pemrograman python dan memanfaatkan gunicorn sebagai server untuk menjalankan kode python untuk melayani HTTP.

Middleware Web Service merupakan produk yang bekerja untuk memfasilitasi fungsionalitas antar aplikasi. Middleware Web Service juga dikenal sebagai manajemen dari layanan web yang dapat menangani hal-hal seperti keamanan atau komunikasi lintas platform seperti mengirimkan pesan data atau informasi antar aplikasi yang berbeda. Middleware Web Service ini bekerja sebagai arsitektur client-server di mana aplikasi layanan web adalah client dan middleware adalah server, yaitu menyediakan layanan kepada client. Proses keamanan data ini disebut proses Enkripsi yang merupakan bagian penting dalam proses pengamanan data. Aspek penting dari sebuah sistem yaitu security (keamanan), namun pemilik sistem masih kurang memperhatikan dari keamanan data dari sistem yang telah dibangun. Karena pentingnya pengamanan data.

Penelitian ini bertujuan menjaga kerahasiaan data dengan mengekripsikan data menggunakan triple key Md5, Base64 dan AES pada pemrograman python dan menjaga kerahasiaan data EKTP dari proses Tag NFC. Dimana pada penelitian ini mengangkat teknik pengamanan data menggunakan kriptografi yang membuat pengamanan atau kerahasiaan data E-KTP saat proses tag NFC di ruangan informatics research center (IRC) yang memungkinkan data E-KTP tidak terbaca oleh pengguna yang tidak memiliki akses, dengan encryption data atau informasi menjadi lebih sulit untuk diketahui oleh pengguna yang tidak memiliki akses. Dengan 
pengamanan maka pemilik E-KTP terhindar dari penyadapan atau pembajakan data penting. Proses enkripsi pada penelitian ini menggunakan kombinasi algoritma Md5, Base64 dan AES, untuk memberikan hasil berbentuk (chipertext).

Dengan demikian penelitian ini menggunakan triple key Md5, Base64 dan AESyang merupakan algoritma untuk Encoding dan Decoding suatu data. Kombinasi ini diharapkan dapat memperkuat keamanan data atau pesan yang bersifat rahasia, sehingga akan lebih sulit untuk di pecahkan oleh orang-orang yang tidak berhak terhadap data tersebut.

\section{METODE}

Penelitian ini membahas tentang mengamankan data dengan cara mengenkripsi menggunakan triple key Md5, Base64 dan AES, Adapun penjelasan beserta contohnya dari ketiga algoritma tersebut sebagai berikut:

a. AES: AES Cipher Blocker Chaining (CBC) merupakan bentuk lanjutan dari generasi pertama Enkripsi Cipher Blok (ECB). Dengan enkripsi CBC, setiap blok ciphertext tergantung pada semua blok plaintext yang diproses untuk menambah tingkat kerumitan data yang telah dienkripsi. Contoh enkripsi AES CBC dari kata "Anak Teknik" menjadi "wkL5tGCFUkVptwZRi/UG8g==".

b. Base64: Algoritma Base64 digunakan dalam penelitian ini karena merupakan algoritma untuk encryption dan decryption ke dalam format ASCII. Contoh penggunaan dari Algoritma Base64 dalam melakukan enkripsi karakter. Kutipan dari Albert Einstein: "Imajinasi lebih penting dari pengetahuan" adapun hasil enkripsi "SW1hamluYXNpIGxIYmloIHBIbnRpbmcgZGFyaSBwZW5nZXRhaHVhbg==".

C. MD5: Algoritma MD5 merupakan sebuah pesan dengan ukuran panjang message digest 128 bit, secara brute force dibutuhkan percobaan sebanyak 2128 kali untuk menemukan dua buah pesan atau lebih yang sama (Sumarno \& others, 2018). Contoh penggunaan Algoritma MD5 dalam melakukan enkripsi karakter nya "Sayang Kamu" dan hasil enkripsi "7DBC90A494B88410686214D2A0C877B9".

Metodologi penelitian merupakan aturan kegiatan, dan prosedur yang digunakan oleh seorang peneliti. Metodologi juga merupakan sebuah analisa teoritis tentang suatu cara. Berikut ini adalah alur dari metodologi penelitian yang dilakukan di dalam penelitian ini yang dapat dilihat pada Gambar 1.

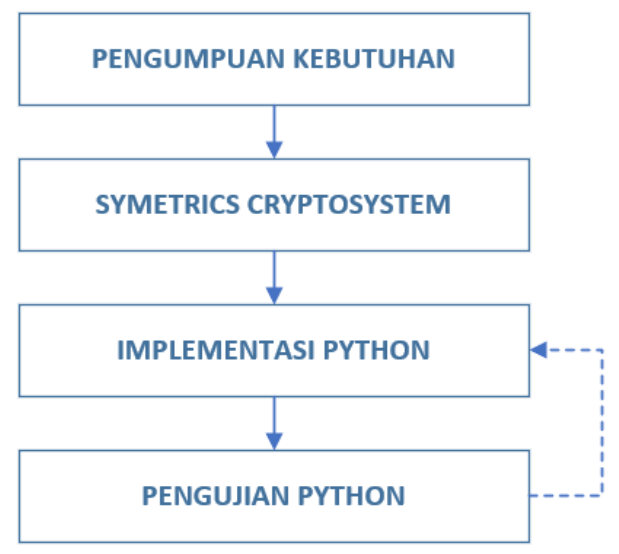

Gambar 1. Tahapan Metodologi Penelitian

Jurnal Tekno Insentif - 67 


\subsection{Pengumpulan Kebutuhan}

Mengumpulkan kebutuhan sistem enkriptor seperti data. Data penelitian ini diperoleh dari pengguna atau pengurus Informatics Research Center (IRC), data yang digunakan merupakan data E-KTP. Data tersebut akan di enkripsi untuk menjaga kerahasiaan menggunakan kriptografi.

\subsection{Symetric Cryptosystem}

proses Symetric Cryptosystem pada enkripsi yaitu mengganti huruf dari data atau informasi plaintext menjadi ciphertext. Proses pergantian dilakukan dengan melangkahi huruf setelahnya seperti huruf a digantikan dengan huruf $f$ dan seterusnya, dan proses pengembalian huruf data atau informasi disebut dengan deskripsi.

\subsection{Implememtasi Python}

Proses pada implementasi python ini menerjemahkan hasil dari proses enkripsi dan deskripsi ke dalam bahasa pemrograman python untuk menjaga kerahasiaan data E-KTP dari proses $\operatorname{tag} N F C$.

\subsection{Pengujian Python}

Tahapan ini merupakan tahapan akhir, pada tahap ini akan didapatkan hasil dari identifikasi masalah pada penelitian ini. Pengujian ini menggunakan BOOM untuk melihat hasil implementasi python apakah ada terdapat masalah atau error, jika tidak maka aman untuk digunakan.

\section{HASIL DAN PEMBAHASAN}

Penelitian ini membahas tentang bagaimana menjaga kerahasiaan data E-KTP dari proses tag NFC. dengan cara mengenkripsi menggunakan kombinasi algoritma kriptografi Triple Key Md5, Base64 dan AES, dan diimplantasikan pada bahasa pemrograman python.

\subsection{Pengumpulan Kebutuhan}

Data kebutuhan yang diperoleh dan dikumpulkan langsung dari pengguna laboratorium IRC, seperti Dosen pengurus IRC dan Mahasiswa DIV Teknik Informatika Politeknik Pos Indonesia yang menggunakan laboratorium IRC sebagai tempat sarana penelitiannya. Berikut data yang akan dilakukan nya proses enkripsi dan enkripsi pada penelitian ini yang dapat dilihat pada Tabel 1.

Tabel 1. Data dari Proses Tag NFC

\begin{tabular}{|c|c|c|}
\hline Id_tap & Id_pengguna & Tanggal \\
\hline 1 & $0 \times 40 \times 360 \times 380 \times B 20 \times 210 \times 250 \times 80$ & 19/07/2019 10:02:12 \\
\hline 2 & $0 \times 50 \times 8 A 0 \times 990 \times 1 E 0 \times 590 \times 310 \times 0$ & 19/07/2019 10:02:12 \\
\hline 3 & $0 \times 40 \times 8 A 0 \times 610 \times B A 0 \times 410 \times 2 A 0 \times 80$ & $21 / 08 / 201914: 15: 57$ \\
\hline 4 & $0 \times 40 \times 840 \times 7 \mathrm{~A} 0 \times 5 \mathrm{~A} 0 \times 810 \times 2 \mathrm{~A} 0 \times 80$ & $21 / 08 / 201914: 15: 57$ \\
\hline 5 & $0 \times 40 \times 310 \times 570 \times 5 A 0 \times 7 D 0 \times 5 B 0 \times 80$ & $21 / 08 / 201914: 15: 57$ \\
\hline 6 & $0 \times 40 \times 600 \times 590 \times C A 0 \times 5 B 0 \times 2 A 0 \times 80$ & $21 / 08 / 201914: 20: 41$ \\
\hline 7 & 0x40x5E0x910xE20x9E0x4F0x80 & $21 / 08 / 201914: 20: 41$ \\
\hline 8 & $0 \times 40 \times 840 \times 7 A 0 \times 5 A 0 \times 810 \times 2 A 0 \times 80$ & $21 / 08 / 201914: 24: 00$ \\
\hline 9 & $0 \times 40 \times 230 \times 240 \times F A 0 \times 800 \times 5 B 0 \times 80$ & $21 / 08 / 201916: 40: 27$ \\
\hline 10 & $0 \times 40 \times 360 \times 380 \times B 20 \times 210 \times 250 \times 80$ & $27 / 08 / 201907: 53: 28$ \\
\hline 11 & $0 \times 40 \times 360 \times 380 \times B 20 \times 210 \times 250 \times 80$ & 27/08/2019 07:53:28 \\
\hline
\end{tabular}


Adapun Dosen pengurus IRC dan Mahasiswa DIV Teknik Informatika Politeknik Pos Indonesia yang menggunakan laboratorium IRC dapat dilihat pada Tabel 2.

Tabel 2. Data Pengurus IRC

\begin{tabular}{|c|l|l|}
\hline id_p & \multicolumn{1}{|c|}{ id_pengguna } & \multicolumn{1}{c|}{ nama_p } \\
\hline 1 & $0 \times 40 \times 360 \times 380 \times B 20 \times 210 \times 250 \times 80$ & Muhammad Nur Ikhsan \\
\hline 2 & $0 \times 40 \times 5 E 0 \times 910 \times E 20 \times 9 E 0 \times 4 F 0 \times 80$ & Alit Fajar Kurniawan \\
\hline 3 & $0 \times 50 \times 8 A 0 \times 990 \times 1 E 0 \times 590 \times 310 \times 0$ & Maulyanda \\
\hline 4 & $0 \times 40 \times 1 E 0 \times 600 \times 6 A 0 \times C 60 \times 610 \times 80$ & Syafrial Fachri Pane \\
\hline 5 & $0 \times 40 \times 1 \mathrm{C} 0 \times 2 E 0 \times A 0 \times 420 \times 2 A 0 \times 80$ & Rolly Maulana Awangga \\
\hline 6 & $0 \times 40 \times 310 \times 570 \times 5 A 0 \times 7 D 0 \times 5 B 0 \times 80$ & Cahya Kurniawan \\
\hline 7 & $0 \times 40 \times 600 \times 590 \times C A 0 \times 5 B 0 \times 2 A 0 \times 80$ & Aditya Pratama Dharma \\
\hline 8 & $0 \times 40 \times 230 \times 240 \times F A 0 \times 800 \times 5 B 0 \times 80$ & M Raziq Hakim Siregar \\
\hline 9 & $0 \times 40 \times 840 \times 7 A 0 \times 5 A 0 \times 810 \times 2 A 0 \times 80$ & R Rifa Fauzi Komara \\
\hline 10 & $0 \times 40 \times 8 A 0 \times 610 \times B A 0 \times 410 \times 2 A 0 \times 80$ & Faisal Syariffudin \\
\hline
\end{tabular}

\subsection{Symetric Cryptosystem}

Untuk menjaga kerahasiaan data pada penelitian ini menggunakan Symetric Cryptosystem sebagai kunci untuk melakukan proses encryption dan decryption. Kunci dari proses tersebut harus dirahasiakan untuk menjaga kerahasiaan data atau informasi proses tag NFC. Proses Alur Diagram dari Symetric Cryptosystem dapat dilihat pada Gambar 2.

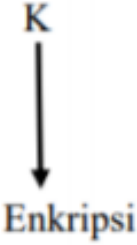

Plaintext
Ciphertext
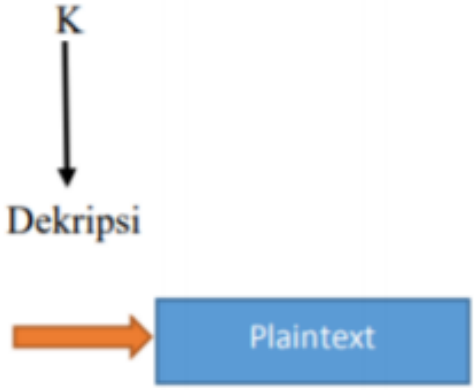

\section{Gambar 2. Diagram Symetric Cryptosystem}

Kunci untuk melakukan proses encryption dan decryption adalah kunci yang sama (K). Langkah-Langkah detail dari (K) dalam proses enkripsi dan dekripsi dengan penerapan algoritma kriptografi yang dirancang dapat dilihat pada Gambar 3 dan Gambar 4.

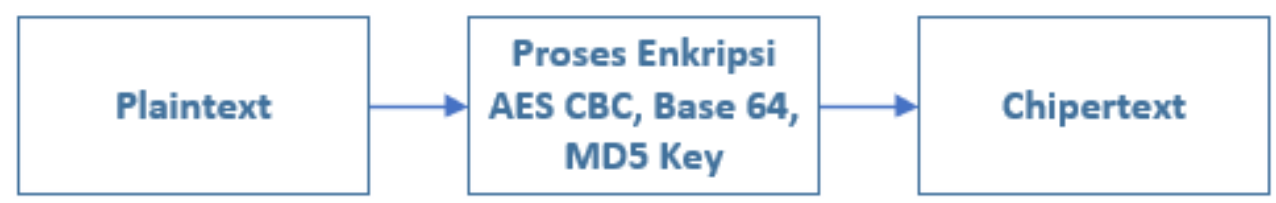

Gambar 3. Proses Encryption 


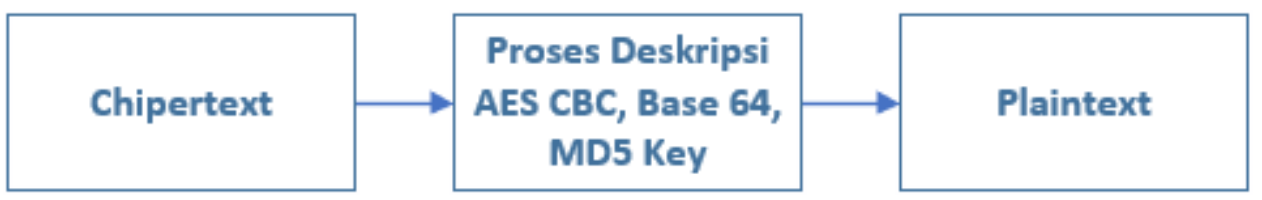

\section{Gambar 4. Proses Decryption}

\subsection{Implementasi Python}

Tahap ini merupakan proses dari enkripsi dan deskripsi ke dalam bahasa pemrograman python sebagai kerangka kerja dalam pembuatan sistem. Struktur project yang dibuat hanya menggunakan 2 file, yaitu pliku.py dan otak.py yang dapat dilihat pada Gambar 5.

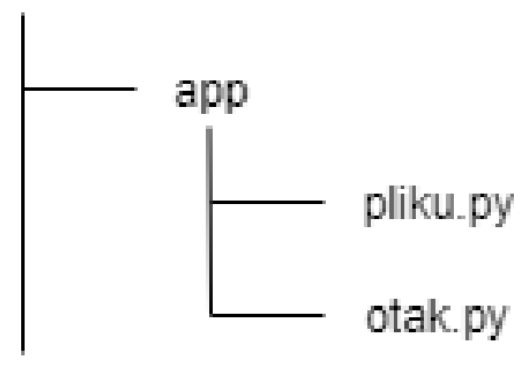

\section{Gambar 5. Struktur Project}

Pada file pliku.py terdapat proses dari logika kriptografi, seperti enkripsi dan dekripsi yang mengombinasikan AES CBC, Base64 dan MD5. Hasil akhir dari proses enkripsi ini berupa chipertext, sedangkan proses akhir dari dekripsi ini berupa plaintext dari hasil proses data yang berbentuk chipertext. Adapun code yang terdapat pada file pliku.py sebagai berikut:

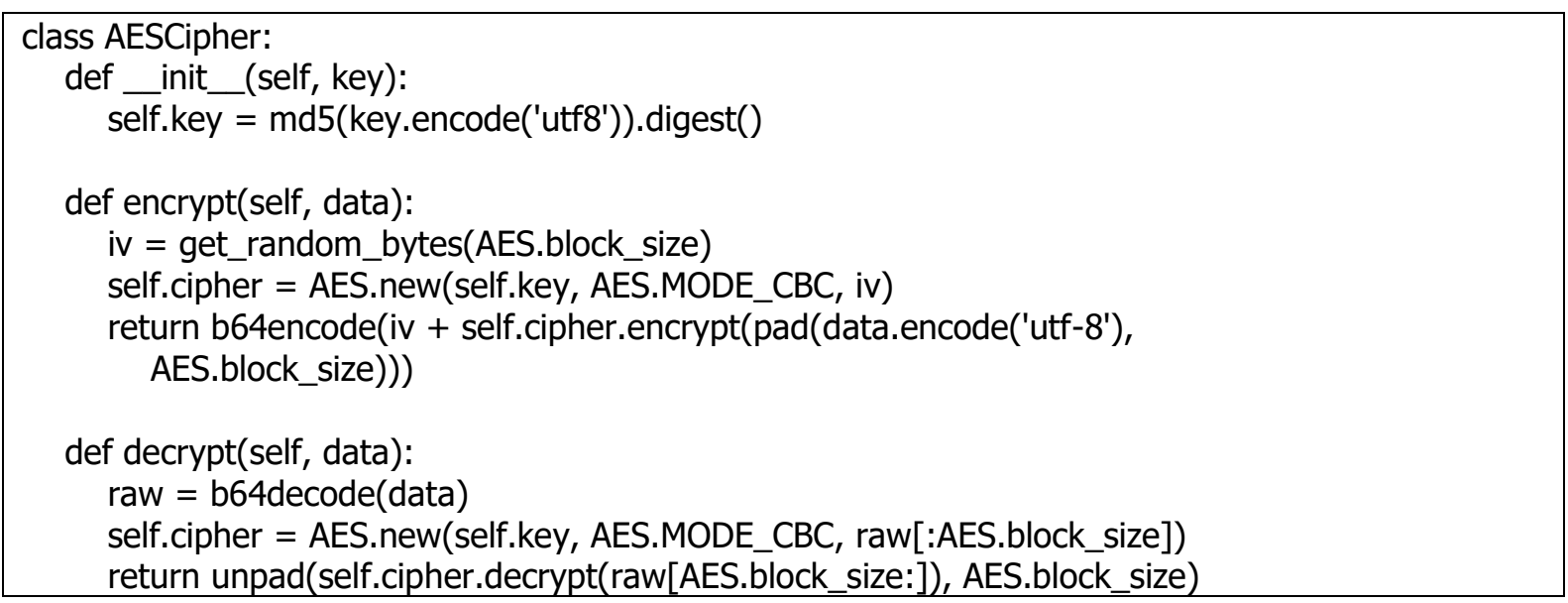

File otak.py adalah sebagai tempat route aplikasi dari proses enkripsi dan deskripsi. Pada proses enkripsi menerapkan metode GET untuk mendapatkan data dari proses enkripsi dari file pliku.py, sebelum mendapatkan data pada proses enkripsi ini akan melakukan proses cek token terlebih dahulu sebagai keamanan lebih dari proses enkripsi ini. Adapun code pada proses enkripsi dapat dilihat sebagai berikut:

def token_required(f):

@wraps(f)

def decorated(*args, **kwargs):

token $=$ request.args.get('token') 


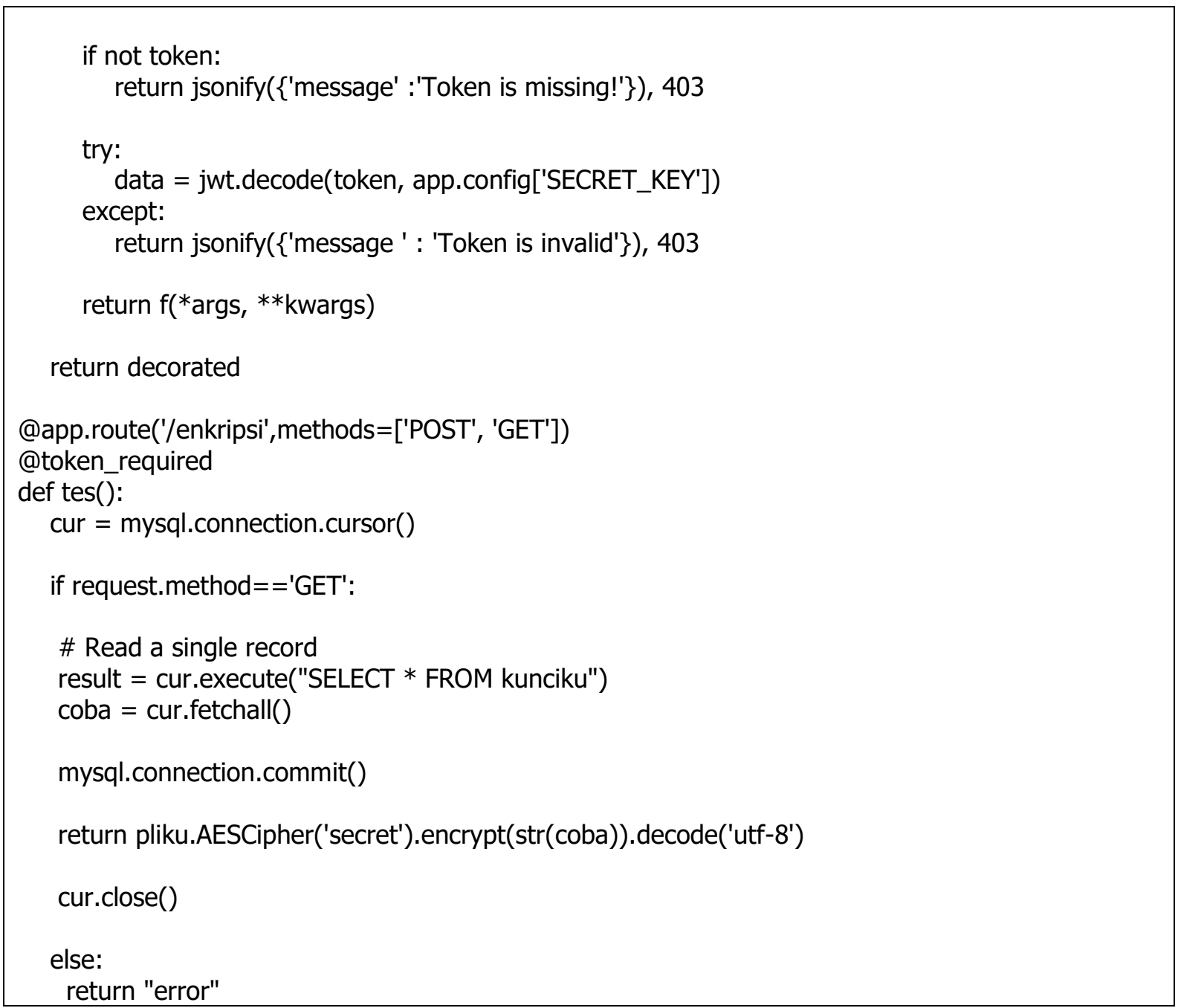

Hasil dari proses enkripsi seperti yang dapat dilihat di bawah ini merupakan hasil dari kombinasi AES CBC, Base64 dan MD5 yang berbentuk chipertext (teks tersandi) dari proses enkripsi.

yLA0UOqBo7aLBAwKtYgwg5m4pBDzPiXcnnRYBfatN+txeGVdwKt46BJBpYO4YTP/9WI6Jt5r+/KUjdBi WsAWAv7XImm2Dcdoe0rNi9f47su7Ny6IUreBKVQYU8KAD0LdIsDWtgW+2V+1UM8DdcjHtWIOByiE/j 2zpskroLQZ2mse1p8NRO1JtAB/agH3KuSN96cAjzRBaEID4QEwWEGI9zNWmlqIzAjG6hXrmGfPgkO2O 6u1h2lOsHarRyuVm3sbExYJ3zPqeCLhJOoF6BJ029Er6JBuzwg1S4+ZK5qqEg2CYn20Vnr70JK9hdOrCB ZPgPgOOROUnzEaWtWy9BEidrqQpfEGbIwy111ZAYCNHvLkT3B3WWO7IIxIBUmkSFmsS6HDqCAC1jx o9ds12amtgZgLcoS3iVoUuUhgUw7mJfH+OKKQfkzocjct0EgXLM/+TVdtqUFI+RVwPoW2sWsBhMsMv d/byU/sKLKFqpiUNHL1/XhbIlYwvM7ND7djXy3PigYxhGbNGfo9kxNa4zO2kRygOViBq1yWWWqZT04HT UMljnyVaxBhGk6LCIWbfQyldt0BHdL51Akf6Y/lv2vOBZaHrP80Bc+yHK6eJIPQ3lvZJ1a9FRtPi4hjZEmeJ/i ilzfr+EUoYdZ3xbGm12c0yOaqqOygoyNJziYYLFpuYVE8rwTd1NOYGKYCzrz4OuHubh2yPKzr3XVHRKko 7oB3UdEYXEwHu0WmUhbj6sIGoAklv24NSNw45XQIwrMNtfES/GtIxPGZabn1j2L7J1Rjxoc9e9HdqaGR OwpmY4xPuV9GE3C9UCZOCZUpHXvC2jcWfYXVxIAuywbBfEgQZgTvvLkA6gsHmey7MC7uzHwQn3FW 0zJi8H4d40FMHg8Sdx6FmMZ8p1hTjEbYhk8EnD0xhLFY8evWc7joy2NKpLZJ90n0R8IxhlY/G6Ymi1ihg4 5GvKE6J2KtjY7pTIsyTVS43bgkg7X3SNd4iO7K+cU1vL/JK04wCWQyNOCRYa+a29rUXW1ZOWWK19s eW4DZ2rXEU3GBLCsqTS/05qOn6WwraBBT6938GYLvJv9EZhVQMXW7V2nMNvGsI4B+QuyQgzZoA63 FBXm6gB4w9sF/m0ndjV87H+UD6/Uf41YxvoJCV0ao8ZJ80VYU32343Fge2FeJK4SE2PvBn98KbEoJDo wLH4jfxGbZVsppVxoiB1DKuiYeW+jdKSj63M0EuRD5qkngKTa3Sgt0nbP6Nxrheaokqb6t8irAwcVDicU+ WIHeQqZ5FKOSkvgmC5wEud3m1jTU9SVkDQnpGkLrT2izzxe0oVjYN3gZcjd0TKRD8XDQP+wgTSQsQ 
vCrJIyjpAcRwcQHZhvfbiHQNyRp3zRPyHKs5/ia86ZzQV7cB/4PkiS/XiUiP20Tziw8FgHlkBE0gDReX675U sHLiuoM4IM5/JiM/27DaAyE3KhDXzNSnkUnYLMGV+8TE1WwkuRTIMOJSmG7LWHvc7bwgIIRC3oa41 s4JwX6KU6tv10wC1B0YgilPFUZSXCJ1/uXXKfif+C7e8OrPw0jcRsi75OsaZnVdfZ7dSDJn3gTt61JSnH5s0 zoJS4dENGbSADIzCmsT67UGO6AU74TvtRditWJbrMZtsKhAgHctIWCGOxDDtG/r6Xy41nNxXadByL/Y7 UbV2gkwuoJ5nHaWZwnqxOw40scTYFwHcBphqpKPmbVR+BvIX3amFXePp2dfdhp1y8ZN87VhDICshR nNQ8ncWLbUpCuj/4ILZ+huzc3FjJQzEx6JSNogzOewF2Dk753TY/TWb8iMw73ch6RmLfOVT7ZBnFXjGb 11x6Uk/NdkasAjAf9N3VxGHPaABaSO9QYwQISq+B/ChDyMRY1C2/4ilXxfO05y2o/u4fNowZnXMaxe8p 22c+ItXCIN6CdwoahFjxXgEfdY6eGcMvsUT00LYq0vqq4EtWUQIAXIa0GHimGvDxYXV7GGFN49wCGm QCDahueHcR8509bSw $==$

Sedangkan pada proses dekripsi menggunakan metode POST untuk melakukan proses dekripsi dari data enkripsi yang berbentuk chiptertext menjadi plaintext. Sebelum mendapatkan hasil hampir sama dengan proses enkripsi, pada proses dekripsi akan mengecek token sebagai keamanan lebih sebelum mendapatkan hasil dari proses dekripsi ini. Adapun code pada proses dekripsi dapat dilihat sebagai berikut:

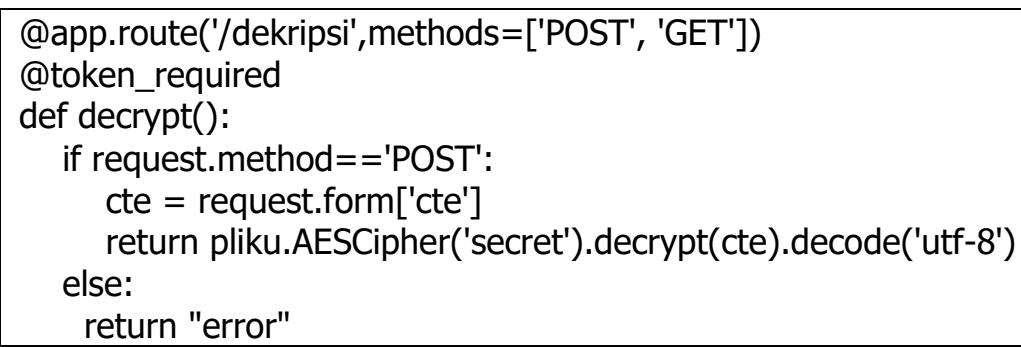

Hasil dari proses deskripsi ini merupakan hasil proses dekripsi dari data berbentuk chiptertext yang didapatkan pada proses enkripsi menjadi plaintext, sehingga data tersebut dapat dilihat dalam bentuk format XML.

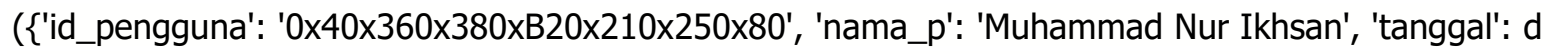

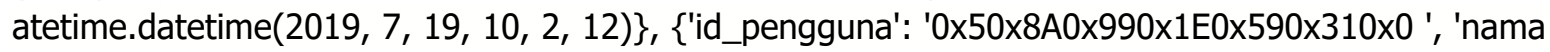
_p': 'Maulyanda', 'tanggal': datetime.datetime(2019, 7, 19, 10, 2, 12)\}, \{'id_pengguna': '0x40x8A0x 610xBA0x410x2A0x80', 'nama_p': 'Faisal Syariffudin', 'tanggal': datetime.datetime(2019, 8, 21, 14,

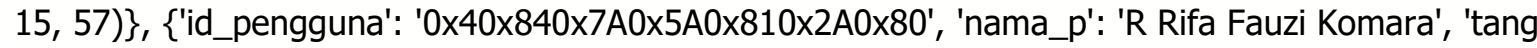

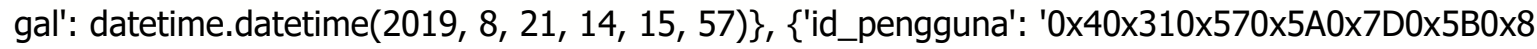
0', 'nama_p': 'Cahya Kurniawan', 'tanggal': datetime.datetime(2019, 8, 21, 14, 15, 57)\}, \{'id_pengg una': '0x40x600x590xCA0x5B0x2A0x80', 'nama_p': 'Aditya Pratama Dharma', 'tanggal': datetime.da tetime (2019, 8, 21, 14, 20, 41)\}, \{'id_pengguna': '0x40x5E0x910xE20x9E0x4F0x80', 'nama_p': 'Alit Fajar Kurniawan', 'tanggal': datetime.datetime(2019, 8, 21, 14, 20, 41)\}, \{'id_pengguna': '0x40x840 x7A0x5A0x810x2A0x80', 'nama_p': 'R Rifa Fauzi Komara', 'tanggal': datetime.datetime(2019, 8, 21, 14, 24)\}, \{'id_pengguna': '0x40x230x240xFA0x800x5B0x80', 'nama_p': 'M Raziq Hakim Siregar', 'ta nggal': datetime.datetime(2019, 8, 21, 16, 40, 27)\}, \{'id_pengguna': '0x40x360x380xB20x210x250x 80', 'nama_p': 'Muhammad Nur Ikhsan', 'tanggal': datetime.datetime(2019, 8, 27, 7, 53, 28)\}, \{'id_

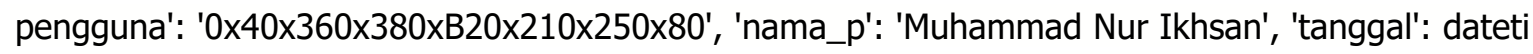
me.datetime $(2019,8,27,7,53,28)\})$

\subsection{Pengujian Python}

Proses pengujian python ini menggunakan BOOM yang merupakan paket tester dari python dimana BOOM merupakan pengganti Apache Bench yang fungsinya akan melihat kinerja dari sistem enkripsi dan dekripsi yang telah dibuat dengan bahasa pemrograman python seperti 
keamanan. Dalam pengujian ini menggunakan 100 kueri dengan maksimum 10 pengguna, berikut adalah hasil dari pengujian menggunakan BOOM yang dapat dilihat pada Gambar 6.

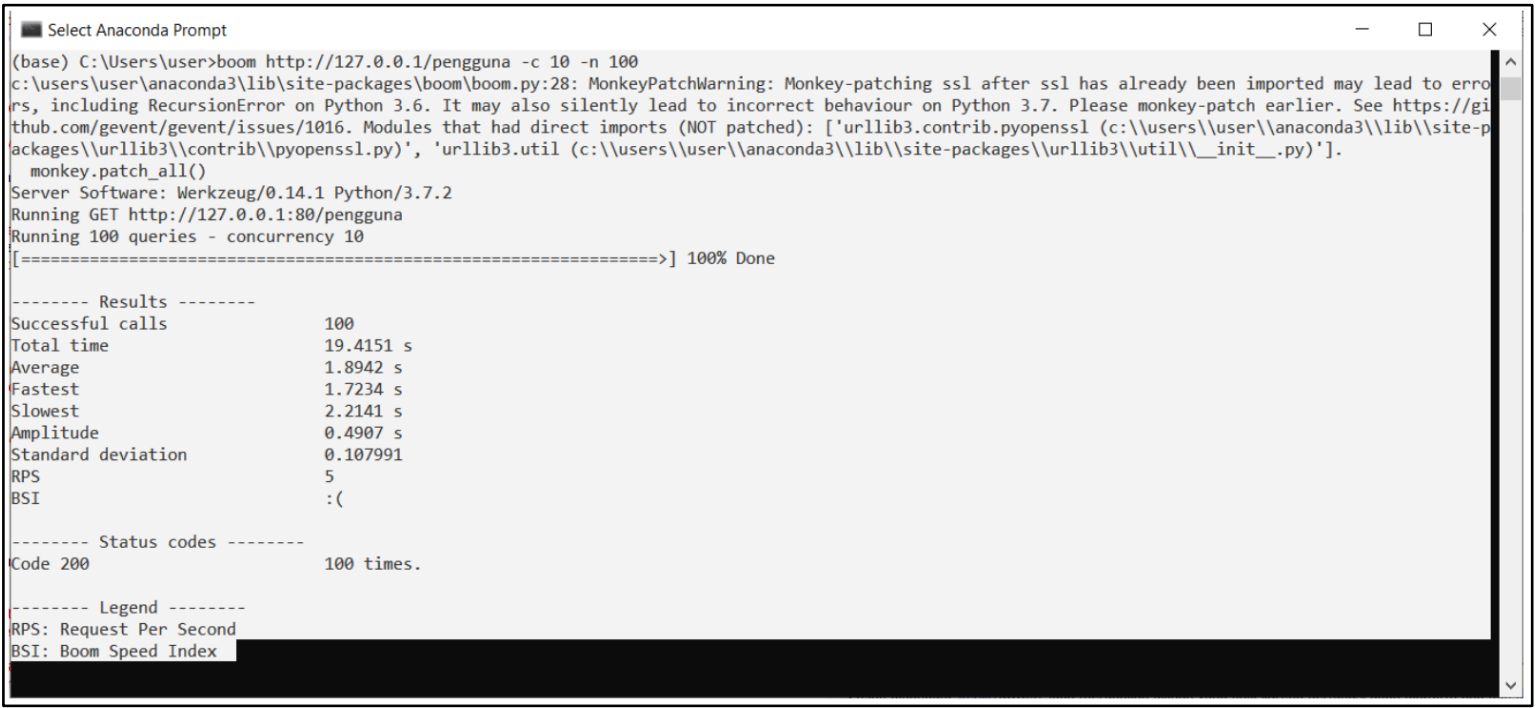

\section{Gambar 6. Hasil Pengujian Menggunakan BOOM}

Dari hasil pengujian yang telah dilakukan seperti pada Gambar 6, didapatkan hasil persentase $100 \%$ keberhasilan terhadap pengujian code program aplikasi, tidak terdapat masalah atau error pada proses simulasi sistem kriptografi pada penelitian ini. Sehingga dikategorikan aman untuk digunakan.

\section{KESIMPULAN}

Setelah melakukan proses enkripsi dan deskripsi dengan menerapkan Triple Key Md5, Base64 dan AES, untuk menjaga kerahasiaan data proses tag NFC. Kesimpulan penelitian sebagai berikut:

1. Penelitian ini berhasil menerapkan algoritma kriptografi menggunakan triple key Md5, Base64 dan AES untuk enkripsi data E-KTP dari proses tag NFC di ruangan Informatics Research Center (IRC) yang memungkinkan data E-KTP tersebut aman dan tidak dapat terbaca oleh pengguna yang tidak memiliki akses;

2. Penelitian ini telah berhasil membuat encrypt dan decrypt, dan di implementasikan pada bahasa pemrograman python. Encrypt dan Decrypt digunakan untuk merahasiakan data E-KTP pada organisasi dengan mengombinasikan Triple Key algoritma kriptografi MD5, BASE64 dan AES;

3. Proses pengujian menggunakan metode BOOM yang merupakan paket tester dari python, didapatkan persentase $100 \%$ keberhasilan dan tidak terdapat error dari sistem algoritma kriptografi yang menggunakan bahasa pemrograman python, sehingga proses keamanan nya aman untuk digunakan.

\section{DAFTAR RUJUKAN}

Awangga, R. M., \& Andarsyah, R. (2016). Pengukuran Performansi Penerapan Asynchronous Daemon Pada Web Service Verifikasi User Di Banana Pi Dengan Metode Benchmarking. Jurnal Teknik Informatika, 8, 1--13. 
Budianto, W., Amini, S., \& Ariyani, P. F. (2017). Aplikasi Pengamanan Dokumen Digital Menggunakan Algoritma Kriptografi Advanced Encryption Standard (Aes-128), Kompresi Huffman Dan Steganografi End Of File (Eof) Berbasis Desktop Pada Cv. Karya Perdana. Prosiding SNATIF, 273--280.

Carter, F. W., Khaire, T. S., Novosad, V., \& Chang, C. L. (2016). scraps: An open-source Python-based analysis package for analyzing and plotting superconducting resonator data. IEEE Transactions on Applied Superconductivity, 27, 1--5.

Christanto, A. T., \& Kurniawati, R. (2016). Penerapan Service Oriented Architecture Menggunakan Web Service Pada Aplikasi Perpustakaan Berbasis Android.

Hidayat, A. D., \& Afrianto, I. (2017). Sistem Kriptografi Citra Digital Pada Jaringan Intranet Menggunakan Metode Kombinasi Chaos Map dan Teknik Selektif. Ultimatics: Jurnal Teknik Informatika, 9, 59--66.

López, A. F., Pelayo, M. C., \& Forero, Á. R. (2016). Teaching image processing in engineering using python. IEEE Revista Iberoamericana de Tecnologias del Aprendizaje, 11, 129-136.

Masoumi, M., \& Rezayati, M. H. (2014). Novel approach to protect advanced encryption standard algorithm implementation against differential electromagnetic and power analysis. IEEE Transactions on Information Forensics and Security, 10(2), 256--265.

Moudgalya, K. (2018). Crowdsourced information technology content for education and employment. Dalam 2018 IEEE 18th International Conference on Advanced Learning Technologies (ICALT) (hal. 39--41). IEEE.

Pane, S. F., Awangga, R. M., \& Azhari, B. R. (2018). Qualitative evaluation of RFID implementation on warehouse management system. Telkomnika, 16, 1303--1308.

Pane, S. F., Awangga, R. M., \& Maulyanda. (2018). Sireuboh: Klasifikasi Data Lokasi Barang Menggunakan Region Of Interest (ROI) dan Algoritma Ransac. Jurnal Tekno Insentif, $12,36--40$.

Panjaitan, Y. G., Susanto, A., \& WM, I. U. (2017). Enkriptor-Dekriptor Isi E-Mail Berbasis Android Dengan Algoritma Blowfish. Simetris: Jurnal Teknik Mesin, Elektro dan Ilmu Komputer, 8, 193--200.

Permana, D. S., Praja, A. S., Fatkhuroyan, F., \& Muzayanah, L. F. (2018). Pengolahan dan pemulihan data radar cuaca menggunakan wradlib berbasis python. Jurnal Meteorologi Dan Geofisika, 17. 
Rohman, F. D., \& Mufti, M. (2018). Implementasi Kriptografi Pada Pengiriman Pesan Email Dengan Menggunakan Metode Rc4 Dan Blowfish Berbasis Web Pada Pt. Dascom Jaya Sakti. SKANIKA, 1, 788--793.

Sibarani, E. B., Zarlis, M., \& Sembiring, R. W. (2017). Analisis Kripto Sistem Algoritma AES Dan Elliptic Curve Cryptography (Ecc) Untuk Keamanan Data. InfoTekJar: Jurnal Nasional Informatika dan Teknologi Jaringan, 1, 106--112.

Siswanto, S., Anif, M., \& Gata, W. (2018). Penerapan Algoritma Kriptografi TEA Dan Base64 Untuk Mengamankan Email Data Policy Asuransi. Jurnal ELTIKOM: Jurnal Teknik Elektro, Teknologi Informasi dan Komputer, 2(1), 34--41.

Sumarno, S., \& others. (2018). Analisis Kinerja Kombinasi Algoritma Message-Digest Algortihm 5 (MD5), Rivest Shamir Adleman (RSA) dan Rivest Cipher 4 (RC4) Pada Keamanan EDokumen. Jurnal Sistem Informasi dan IImu Komputer Prima (JUSIKOM PRIMA), 2.

Tibau, M. a., Nunes, B. P., Bortoluzzi, M., \& Marenzi, I. (2018). Modeling exploratory search as a knowledge-intensive process. Dalam 2018 IEEE 18th International Conference on Advanced Learning Technologies (ICALT) (hal. 34--38). IEEE. 